\section{If you go down to the woods today...}

\section{Paul Richards}

The Primary Source: Tropical Forests and Our Future.

By Norman Myers.

W.W. Norton: 1984. Pp.399. \$17.95, £13.50.

TROPICAL forests are shrinking fast. Many believe that they may hardly survive into the next century, but books about them continue to multiply. Dr Myers's is only the latest in an outburst of publications which range from specialist volumes and authoritative texts, such as T.C. Whitmore's Tropical Rain Forests of the Far East*, to semi-popular illustrated books and magazine articles.

The Primary Source is aimed mainly at non-specialists, but will also hold the interest of specialists. It is very readable and the author has the gift of explaining complex matters, such as the hydrological cycle of Amazonia, in simple, comprehensible language. Unlike most books on tropical forests, it is mainly concerned, not with the forests themselves, but with the

*The second edition of this book has just been published by Oxford University Press, price $£ 40, \$ 67.50$.

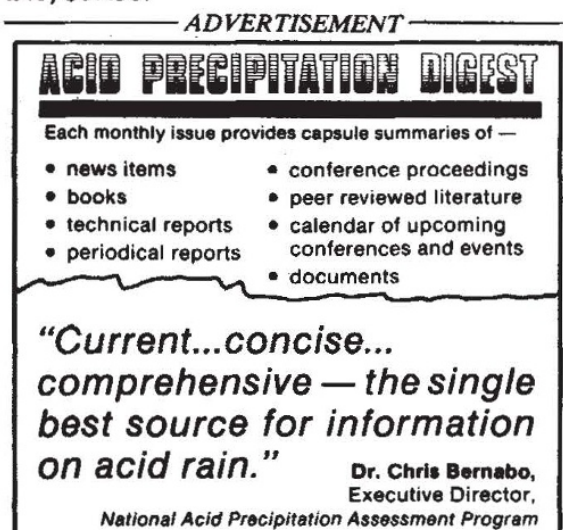

\section{Subscriptions (one year): \\ Corporate, For-Profit Firms, \$125; Government Agencies, $\$ 65$; Nonprofit organizations (including public and academic libraries), $\$ 30$. Non-affiliated individuals -inquire for rates. Add $\$ 15$ for foreign airmail postage ( $\$ 5$ for Canada). Make checks/money orders payable to: Acid Precipitation Digest.}

Published by the nonprofit, non-advocacy

Acid Rain Information Clearinghouse a project of the

Center for Environmental Information, Inc.

Department N, 33 South Washington Street Rochester, New York 14608 (716)546-3796 impact of modern man on them - their destruction by commercial loggers, fuelwood gatherers, cattle raisers and shifting cultivators - as well as with their actual (and potentially much greater) contribution to human welfare. Dr Myers is well qualified to write about this topic: he has spent many years in Africa and more recently made a comprehensive survey of the current state of "forest conversion" in the humid tropical countries on behalf of the U.S. National Research Council's Committee on Research Priorities in Tropical Biology.

Dr Myers interprets the term "tropical forests" very widely; indeed, when he writes about the economic possibilities of water hyacinths and capybaras one wonders whether his subject is not really the whole flora and fauna of the tropics. The opening chapters ("Bio-ecological Background") are" the only ones dealing with the forest as such; they emphasize its richness in species and its ecological complexity. Some statements here are questionable, for example that on p.81 that the seeds of very few tropical trees are wind-dispersed; this is not true and overlooks the function of natural gaps in rain-forest regeneration. Overall the purpose of these early chapters might have been better served had more space been given to illustrations and less to trying to convey a written picture of what a rain forest is "really" like.

In the next section we are on firmer ground. Much of the chapter on commercial logging is fairly familiar, but $\mathrm{Dr}$ Myers gives figures on the insatiable demand of the United States, Japan and other advanced countries for tropical hardwoods which are both striking and disquieting, not least because it is evident that present rates of consumption cannot be maintained; already some tropical countries, such as Nigeria, are reserving what remains of their hardwood stocks for their own use. It is even more disturbing that less than one-twentieth of tropical forests are under management of any kind. A survey of logging companies showed that not one of them leaves enough trees to act as seed-parents for natural regeneration. The accounts of the cattle ranchers and fuel gatherers are also full of information but are no more reassuring.

Still more horrifying is the chapter on shifting cultivators (whom Dr Myers calls "forest farmers"). At least $\mathbf{2 0 0}$ million people depend for survival on the temporary and relatively unproductive farming of small plots won by felling and burning tropical forests. Their numbers are rapidly increasing and have been swollen by incursions of squatters and dispossessed people who lack the simple skills of the traditional forest farmers and are thus even more damaging to the environment.

The effects of human demands on tropical forests might be less tragic if their resources were used fully and rationally. But as the chapters on "Contributions to our Welfare"' show, this is far from true. In conventional tropical forestry, resources are classified into timber and "minor forest products". The latter now include such things as the steroid-yielding tubers of Mexican species of Dioscorea (yams) which are collected from wild plants in the forest and are an export worth millions of dollars. The future possibilities of discovering new drugs and insecticides in tropical forest plants may be enormous and others may provide templates or blue-prints from which such substances could be synthesized. Forest plants may also have uses as sources of protein and of "green gasoline" and other energy-yielding products. In order that the forest resources should be more completely, and less wastefully, used, Dr Myers suggests the establishment of "forest industrial complexes". Of course the products yielded by forests are not their only contribution to human welfare. Other chapters discuss their part in maintaining water supplies, and checking soil erosion and the silting of reservoirs, as well as their effects on the hydrological cycle, albedo and the carbon dioxide content of the atmosphere. The references on these and other topics are up to date and will be very useful for most readers, however expert.

Many readers will turn most eagerly to the final section of the book, "What We Can Do". The political, economic and biological problems are formidable, but $\mathrm{Dr}$ Myers thinks that there is much that can be done both by the citizens of tropical countries and by "outsiders". Basically he believes that the outlook would be brighter if tropical forests were valued at their true worth. Because they are undervalued, forestry departments have always been the Cinderellas of governments in tropical countries; agricultural departments are better supported, but often are more interested in cutting down than in conserving forests. More money is needed for forest protection and for research, and those who understand the importance of forests need to have an effective voice in governments.

Dr Myers sets out what all this implies in some detail, and even provides a "shopping list" for us outsiders which includes such activities as persuading giant corporations to do a better job for tropical forests. Gloomy though the prospects may seem, he remains optimistic, and points to success stories such as the more enlightened attitude to forestry in Indonesia and a change of policy in favour of forestry at the World Bank. But perhaps the most apposite message is the motto from Edmund Burke on the first page of the book: "Nobody makes a greater mistake than he who did nothing because he could do only a little".

Paul Richards is Emeritus Professor of Botany in the University of Wales. He is author of The Tropical Rain Forest, reprinted by Cambridge University Press in 1979. 